\title{
Lifelong learning among Croatian physiotherapy professionals
}

\author{
Gilbert Hofmann \\ PhD student, Department of Information and Communication Sciences \\ Faculty of Humanities and Social Sciences, University of Zagreb \\ Ivana Lučića 3, Zagreb, Croatia \\ gilbert@net.hr \\ Tanja Persoglio \\ Home for abandoned children "Ivana Brlić Mažuranić" \\ Rijeka, Croatia \\ tanjapersoglio@gmail.com
}

\section{Summary}

The aim of the study "Lifelong learning among Croatian physiotherapy professionals" was to examine the attitudes that physiotherapy professionals have towards their professional development. The issue being addressed in the study is their level of motivation for lifelong learning. The basic question to which this study was seeking an answer is outlined in the following hypothesis: "There are statistically significant differences in the dependent variables which relate to lifelong learning with regard to five fundamental independent variables: sex, age, years of service, place of work and qualifications".

1271 respondents participated in the study, i.e. $77 \%$ of the defined population of physical therapists. The survey was carried out in 65 institutions at all healthcare levels, in Croatia, in the period from 1 October 2013 to 31 March 2014. The respondents were men and women between 18 and 65 years of age, and with 1 to 40 years of service. These respondents varied in terms of their place of work (private, regional and national institutions) and professional qualifications (ranging from secondary school degrees up to university degrees).

Keywords: physiotherapy, lifelong learning, professional development.

\section{Introduction}

Nowadays, in time of enormous economic and social change, faced with a demographic situation that is clearly indicating the ageing of the European population, education and learning require a new approach. The concept of lifelong learning pertains to each learning activity embarked upon during one's life that is aimed at enhancing knowledge, skills and competences in personal, civil, social and professional pursuits. [1, 2] Lifelong learning does not apply exclu- 
sively to the working hours - to an individual who is invested in his or her personal and professional development, it applies to the whole working life, as well as the time before and after it.

The concept of lifelong learning is commonly associated with financial goals and one's ability to become more competitive in the job market. The knowledge society contributes to a more active social role of an individual and to his or her social affirmation. Knowledge fosters social inclusion, active personal development and competitiveness on the market. [3] The European Commission's Memorandum on Lifelong Learning defines the new skills that are required for an active participation in the society and knowledge economy. [4] Apart from the traditional skill set, it is essential that one should possess skills in IT, foreign languages, technological culture, entrepreneurship, as well as a set of social skills. Together, they form a new level of the 21st century literacies that allow for an understanding of natural and social processes, critical thinking, successful communication and participation in a multicultural society, entrepreneurial behaviour and permanent learning.

\section{Physiotherapy and lifelong learning}

Physiotherapy is a healthcare profession whose aim is to identify and maximise the quality of life and mobility in the areas of promotion of health, prevention of injury and damage, habilitation and rehabilitation. [5]

Formal education in physiotherapy is based on the Croatian Qualifications Framework (HKO) whose role is to link learning outcomes achieved in all educational institutions, and systematise them at the national and international levels. [6]

Lifelong learning follows after the completion of full-time education and is a statutory requirement for all physical therapists who provide direct healthcare services within their scope of work, as well as for those who work outside the healthcare system as part of the framework for prevention and health promotion. [7] Professional non-formal education available to physiotherapy professionals takes the form of: professional conferences, peer-group meetings that include a lecture, professional advisory sessions, courses and workshops, elearning (online courses).

\section{Research aim and methods}

The subject and the purpose of this study is to examine the attitudes of physiotherapy professionals pertaining tothe lifelong learning they have, more or less, devoted themselves to. The question is to what extent physiotherapy professionals intend to receive education during their working lives. The basic question which this study was seeking to answer is outlined in the following hypothesis: "There are statistically significant differences in the dependent variables which relate to lifelong learning with regard to five fundamental independent variables: sex, age, years of service, employer's organization and qualifications". 
According to the available literature and data, no studies on lifelong learning in physiotherapy have been conducted in Croatia as of yet, which is why this paper could contribute both to popularisation of lifelong learning and its recognition as an indispensible part of advancing one's own professional performance and development. The study used the statistical descriptive correlation method. Empirical data were collected by way of a questionnaire that was created specifically for this study, which consisted of two basic parts:

- General information on the respondent, used to conduct the profile analysis of the respondents who participated in the research.

- A questionnaire on the attitudes of the physiotherapy professionals regarding professional development based on Likert scale criteria.

\section{Results}

The study included 1271 representative respondents, which is $77 \%$ of the defined population when one takes into account the total number of professional employed at institutions where the survey was conducted.The total number of defined population (employees in institutions) is 1650. The survey was carried out in 65 institutions at all healthcare levels, in Croatia, in the period from 1 October 2013 to 31 March 2014. Agroup overview of the results related to the assessment of the attitudes on lifelong learning, based on a Likert scale that was recoded into positive $(4+5)$, neutral $(3)$ and negative attitudes $(1+2)$, is presented in Table 1.

Table 1. Attitudes towards lifelong learning ${ }^{1}$

\begin{tabular}{|c|c|c|c|c|c|c|}
\hline & \multirow[t]{2}{*}{ Statement } & \multicolumn{3}{|c|}{$\begin{array}{c}\text { Attitude value based } \\
\text { on Likert scale }\end{array}$} & \multirow[t]{2}{*}{$\mathbf{M}$} & \multirow[t]{2}{*}{ SD } \\
\hline & & $1+2$ & 3 & $4+5$ & & \\
\hline 1 & $\begin{array}{l}\text { I cover the entire cost of my education (seminars, } \\
\text { trainings, lectures ...) myself }\end{array}$ & 22,3 & 17,7 & 60 & 3,65 & 1,254 \\
\hline 2 & $\begin{array}{l}\text { The employer is interested in my further training } \\
\text { and encourages me to transfer/present knowledge } \\
\text { to my colleagues }\end{array}$ & 41,2 & 29,5 & 29,3 & 2,74 & 1,185 \\
\hline 3 & $\begin{array}{l}\text { I regularly read professional literature, and use the } \\
\text { internet to keep up with the latest developments in } \\
\text { my line of work }\end{array}$ & 12,5 & 15,3 & 72,3 & 3,72 & 0,935 \\
\hline 4 & $\begin{array}{l}\text { Command of foreign languages can help me in } \\
\text { further training or education }\end{array}$ & 4,2 & 8,9 & 87 & 4,15 & 0,809 \\
\hline 5 & $\begin{array}{l}\text { I think it is necessary for educational institutions } \\
\text { to become more involved in the process of lifelong } \\
\text { learning }\end{array}$ & 2,4 & 13,3 & 84,3 & 4,05 & 0,709 \\
\hline
\end{tabular}

A random selection of respondents in the study resulted in a larger number of women $(73,6 \%)$ than men $(26,4 \%)$. Sex-disaggregated data are presented in Table 2.

\footnotetext{
${ }^{1}$ Table legend: $(1=$ strongly disagree $2=$ disagree, $3=$ no opinion $/$ neutral, $4=$ agree, $5=$ strongly agree, $\mathrm{M}=$ mean, $\mathrm{SD}=$ standard deviation.)
} 
Table 2. Differences in responses by sex

\begin{tabular}{|c|c|c|c|c|}
\hline \multicolumn{2}{|r|}{ Statement } & \multirow{2}{*}{$\stackrel{\ddot{D}}{\mathscr{H}}$} & \multirow{2}{*}{$\begin{array}{c}\mathbf{M} \\
3,79 \\
\end{array}$} & \multirow{2}{*}{$\begin{array}{c}\text { SD } \\
1,21 \\
\end{array}$} \\
\hline 1 & I cover the entire cost of my education mycelf & & & \\
\hline 1 & 1 cover tine entire cost or my education mysenti & $\mathrm{F}$ & 3,60 & 1,27 \\
\hline \multirow{2}{*}{2} & \multirow{2}{*}{$\begin{array}{l}\text { The employer is interested in my further training and encourages me to } \\
\text { transfer/present knowledge to my colleagues }\end{array}$} & $\mathrm{M}$ & 2,72 & 1,21 \\
\hline & & $\mathrm{F}$ & 2,74 & 1,18 \\
\hline \multirow{2}{*}{3} & \multirow{2}{*}{$\begin{array}{l}\text { I regularly read professional literature and use the internet to keep up } \\
\text { with the latest developments in my line of work }\end{array}$} & $\mathrm{M}$ & 3,71 & 1,01 \\
\hline & & $\mathrm{F}$ & 3,73 & 0,91 \\
\hline \multirow{2}{*}{4} & \multirow{2}{*}{$\begin{array}{l}\text { Command of foreign languages can help me in further training or } \\
\text { education }\end{array}$} & $\mathrm{M}$ & 4,21 & 0,87 \\
\hline & & $\mathrm{F}$ & 4,13 & 0,79 \\
\hline & \multirow{2}{*}{$\begin{array}{l}\text { I think it is necessary for educational institutions to become more } \\
\text { involved in the process of lifelong learning }\end{array}$} & $\mathrm{M}$ & 4,00 & 0,84 \\
\hline & & $\mathrm{F}$ & 4,07 & 0,66 \\
\hline
\end{tabular}

With regard to age, the respondents were divided into five groups; $18-25$ years of age, 26 - 35 years of age, $36-45$ years of age, $46-55$ years of age, and $56-$ 65 years of age. Information on the respondents and the differences in responses based on age are presented in Tables 3 and 4 .

Table 3. Respondents by age

\begin{tabular}{|l|c|c|c|}
\hline Respondents & Number of respondents & Percentage (\%) & Cumulative percentage (\%) \\
\hline $18-25$ & 142 & 11,2 & 11,2 \\
\hline $26-35$ & 369 & 29,0 & 40,2 \\
\hline $36-45$ & 338 & 26,6 & 66,8 \\
\hline $46-55$ & 325 & 25,6 & 92,4 \\
\hline $56-65$ & 97 & 7,6 & 100,0 \\
\hline TOTAL & $\mathbf{1 2 7 1}$ & $\mathbf{1 0 0 , 0}$ & \\
\hline
\end{tabular}

Table 4. Differences in responses by age

\begin{tabular}{|c|c|c|c|c|}
\hline \multicolumn{2}{|r|}{ Statement } & Group & M & SD \\
\hline \multirow{3}{*}{1} & \multirow{3}{*}{$\begin{array}{l}\text { I cover the entire cost of my education (seminars, trainings, lectures } \\
\text {...) myself. }\end{array}$} & $18-35$ & 3,89 & 1,20 \\
\hline & & $36-55$ & 3,48 & 1,28 \\
\hline & & $56-65$ & 3,57 & 1,19 \\
\hline \multirow{3}{*}{2} & \multirow{3}{*}{$\begin{array}{l}\text { The employer is interested in my further training and encourages me } \\
\text { to transfer/present knowledge to my colleagues }\end{array}$} & $18-35$ & 2,86 & 1,16 \\
\hline & & $36-55$ & 2,64 & 1,20 \\
\hline & & $56-65$ & 2,74 & 1,22 \\
\hline \multirow{3}{*}{3} & \multirow{3}{*}{$\begin{array}{l}\text { I regularly read professional literature and use the internet to keep } \\
\text { up with the latest developments in my line of work }\end{array}$} & $18-35$ & 3,78 & 0,90 \\
\hline & & $36-55$ & 3,67 & 0,96 \\
\hline & & $56-65$ & 3,73 & 0,93 \\
\hline \multirow{3}{*}{4} & \multirow{3}{*}{$\begin{array}{l}\text { Command of foreign languages can help me in further training or } \\
\text { education }\end{array}$} & $18-35$ & 4,31 & 0,75 \\
\hline & & $36-55$ & 4,04 & 0,83 \\
\hline & & $56-65$ & 4,04 & 0,84 \\
\hline \multirow[t]{3}{*}{5} & \multirow{3}{*}{$\begin{array}{l}\text { I think it is necessary for educational institutions to become more } \\
\text { involved in the process of lifelong learning }\end{array}$} & $18-35$ & 4,07 & 0,66 \\
\hline & & $36-55$ & 4,03 & 0,75 \\
\hline & & $56-65$ & 4,07 & 0,71 \\
\hline
\end{tabular}


According to the level of professional qualifications, the respondents are divided into: 1. university graduates in physiotherapy who have completed the appropriate study in physiotherapy at the University of Applied Health Sciences; 2 . bachelors in physical therapy who have completed the appropriate undergraduate professional/academic study in physiotherapy; 3. physiotherapy technicians who have completed a 4-year secondary school programme, and 4. masseurs who have completed the appropriate 3-year secondary school programme. Information on the respondents and the differences in responses are presented in Tables 5 and 6.

Table 5. Respondents by professional qualifications.

\begin{tabular}{|l|c|c|c|}
\hline \multicolumn{1}{|c|}{ Respondents } & $\begin{array}{c}\text { Number of } \\
\text { respondents }\end{array}$ & $\begin{array}{c}\text { Percentage } \\
\mathbf{( \% )}\end{array}$ & $\begin{array}{c}\text { Cumulative } \\
\text { percentage (\%) }\end{array}$ \\
\hline Graduate physiotherapists & 65 & 5,1 & 5,1 \\
\hline Bachelors of physiotherapy & 753 & 59,2 & 64,4 \\
\hline Physiotherapy technicians & 437 & 34,4 & 98,7 \\
\hline Masseurs & 16 & 1,3 & 100,0 \\
\hline TOTAL & 1271 & 100,0 & \\
\hline
\end{tabular}

Table 6. Differences in the responses by professional qualifications.

\begin{tabular}{|c|c|c|c|c|}
\hline \multicolumn{2}{|r|}{ Statement } & Group $^{2}$ & M & SD \\
\hline \multirow{4}{*}{1} & \multirow{4}{*}{$\begin{array}{l}\text { I cover the entire cost of my education (seminars, } \\
\text { trainings, lectures ...) mselft. }\end{array}$} & 1 & 3,97 & 1,311 \\
\hline & & 2 & 3,77 & 1,262 \\
\hline & & 3 & 3,41 & 1,198 \\
\hline & & 4 & 3,13 & 1,088 \\
\hline \multirow{4}{*}{2} & \multirow{4}{*}{$\begin{array}{l}\text { The employer is interested in my further training and } \\
\text { encourages me to transfer/present knowledge to my } \\
\text { colleagues }\end{array}$} & 1 & 2,68 & 1,312 \\
\hline & & 2 & 2,70 & 1,208 \\
\hline & & 3 & 2,80 & 1,129 \\
\hline & & 4 & 2,81 & 1,047 \\
\hline \multirow{4}{*}{3} & \multirow{4}{*}{$\begin{array}{l}\text { I regularly read professional literature and use the } \\
\text { internet to keep up with the latest developments in my } \\
\text { line of work }\end{array}$} & 1 & 4,06 & 0,95 \\
\hline & & 2 & 3,76 & 0,927 \\
\hline & & 3 & 3,61 & 0,929 \\
\hline & & 4 & 3,44 & 0,964 \\
\hline \multirow{4}{*}{4} & \multirow{4}{*}{$\begin{array}{l}\text { Command of foreign languages can help me in further } \\
\text { training or education }\end{array}$} & 1 & 4,40 & 0,703 \\
\hline & & 2 & 4,24 & 0,765 \\
\hline & & 3 & 3,96 & 0,861 \\
\hline & & 4 & 4,00 & 0,816 \\
\hline \multirow{4}{*}{5} & \multirow{4}{*}{$\begin{array}{l}\text { I think it is necessary for educational institutions to } \\
\text { become more involved in the process of lifelong learning }\end{array}$} & 1 & 4,23 & 0,844 \\
\hline & & 2 & 4,10 & 0,675 \\
\hline & & 3 & 3,94 & 0,736 \\
\hline & & 4 & 4,06 & 0,574 \\
\hline
\end{tabular}

2 1. graduate physical therapist; 2. bachelor of physiotherapy; 3 . physiotherapy technician; 4. masseur 
With regard to the length of service, the respondents are divided into five groups; 5 years or less, $6-10$ years, $11-20$ years, $21-30$ years, 31- 40 years, and 40 years of service or more. The data related to the respondents, and the differences in the responses are presented in Tables 7 and 8 .

Table 7. Division of respondents by years of service.

\begin{tabular}{|l|c|c|c|}
\hline Respondents & $\begin{array}{c}\text { Number of } \\
\text { respondents }\end{array}$ & Percentage (\%) & Cumulative percentage (\%) \\
\hline $0-5$ & 259 & 20,4 & 20,4 \\
\hline $6-10$ & 207 & 16,3 & 36,7 \\
\hline $11-20$ & 303 & 23,8 & 60,5 \\
\hline $21-30$ & 292 & 23,0 & 83,5 \\
\hline $31-40$ & 194 & 15,3 & 98,7 \\
\hline 40 or more & 16 & 1,3 & 100,0 \\
\hline TOTAL & $\mathbf{1 2 7 1}$ & $\mathbf{1 0 0 , 0}$ & \\
\hline
\end{tabular}

Table 8. Differences in the responses by length of service.

\begin{tabular}{|c|c|c|c|c|}
\hline \multicolumn{2}{|r|}{ Statement } & Group & M & SD \\
\hline \multirow{4}{*}{1} & \multirow{4}{*}{$\begin{array}{l}\text { I cover the entire cost of my education (seminars, } \\
\text { trainings, lectures ...) myself. }\end{array}$} & $0-10$ & 3,95 & 1,171 \\
\hline & & $11-20$ & 3,58 & 1,352 \\
\hline & & $21-30$ & 3,48 & 1,245 \\
\hline & & 31 or more & 3,31 & 1,155 \\
\hline \multirow{4}{*}{2} & \multirow{4}{*}{$\begin{array}{l}\text { The employer is interested in my further training and } \\
\text { encourages me to transfer/present knowledge to my } \\
\text { colleagues }\end{array}$} & $0-10$ & 2,86 & 1,176 \\
\hline & & $11-20$ & 2,68 & 1,187 \\
\hline & & $21-30$ & 2,65 & 1,191 \\
\hline & & 31 or more & 2,66 & 1,177 \\
\hline \multirow{4}{*}{3} & \multirow{4}{*}{$\begin{array}{l}\text { I regularly read professional literature and use the internet } \\
\text { to keep up with the latest developments in my line of work }\end{array}$} & $0-10$ & 3,82 & 0,878 \\
\hline & & 11-20 & 3,70 & 0,96 \\
\hline & & $21-30$ & 3,64 & 0,976 \\
\hline & & 31 or more & 3,64 & 0,949 \\
\hline \multirow{4}{*}{4} & \multirow{4}{*}{$\begin{array}{l}\text { Command of foreign languages can help me in further } \\
\text { training or education }\end{array}$} & $0-10$ & 4,35 & 0,744 \\
\hline & & 11-20 & 4,12 & 0,859 \\
\hline & & $21-30$ & 4,04 & 0,775 \\
\hline & & 31 or more & 3,91 & 0,822 \\
\hline \multirow{4}{*}{5} & \multirow{4}{*}{$\begin{array}{l}\text { I think it is necessary for educational institutions to } \\
\text { become more involved in the process of lifelong learning }\end{array}$} & $0-10$ & 4,10 & 0,641 \\
\hline & & 11-20 & 4,00 & 0,793 \\
\hline & & $21-30$ & 4,04 & 0,733 \\
\hline & & 31 or more & 4,01 & 0,688 \\
\hline
\end{tabular}

The research was conducted at all levels of healthcare. Variables related to the institutions of employment are described in terms of three categories in the following manner: institutions providing primary and secondary healthcare services are included in the category "Founded by regional government", institutions providing tertiary healthcare services are included in the category "Founded by the central government", private health institutions providing the physical therapy services are included in the category of "Private institutions". 
Information on the respondents and the differences in responses are presented in Tables 9 and 10.

Table 9 Information on the respondents by the institution of employment.

\begin{tabular}{|c|c|c|c|c|c|c|}
\hline \multirow{2}{*}{\multicolumn{3}{|c|}{ Respondents }} & \multicolumn{3}{|c|}{ Healthcare institution } & \multirow[b]{2}{*}{ Total } \\
\hline & & & \multirow{2}{*}{$\begin{array}{l}\text { 1. Founded by } \\
\text { the regional } \\
\text { government }\end{array}$} & \multirow{2}{*}{$\begin{array}{c}\begin{array}{c}\text { 2. Founded } \\
\text { by the } \\
\text { central } \\
\text { government }\end{array} \\
77\end{array}$} & \multirow{2}{*}{$\begin{array}{r}\text { 3. Private } \\
\text { institution } \\
55\end{array}$} & \\
\hline \multirow{6}{*}{$\stackrel{㐅}{\stackrel{\omega}{\omega}}$} & \multirow{3}{*}{$\sum^{\tilde{E}}$} & $\begin{array}{c}\text { Number of } \\
\text { respondents }\end{array}$ & & & & 335 \\
\hline & & Percentage by sex & $60,6 \%$ & $23,0 \%$ & $16,4 \%$ & $100,0 \%$ \\
\hline & & $\begin{array}{c}\text { Percentage by } \\
\text { category sample }\end{array}$ & $25,8 \%$ & $24,3 \%$ & $32,9 \%$ & $26,4 \%$ \\
\hline & \multirow{3}{*}{ 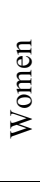 } & $\begin{array}{l}\text { Number of } \\
\text { respondents }\end{array}$ & 584 & 240 & 112 & 936 \\
\hline & & Percentage by sex & $62,4 \%$ & $25,6 \%$ & $12,0 \%$ & $100,0 \%$ \\
\hline & & $\begin{array}{l}\text { Percentage by } \\
\text { category sample }\end{array}$ & $74,2 \%$ & $75,7 \%$ & $67,1 \%$ & $73,6 \%$ \\
\hline \multirow{2}{*}{\multicolumn{2}{|c|}{ Total }} & $\begin{array}{c}\text { Number of } \\
\text { respondents }\end{array}$ & 787 & 317 & 167 & 1271 \\
\hline & & Total percentage & $61,9 \%$ & $24,9 \%$ & $13,1 \%$ & $100,0 \%$ \\
\hline
\end{tabular}

Table 10 Differences in the responses by place of work.

\begin{tabular}{|c|c|c|c|c|}
\hline \multicolumn{2}{|r|}{ Statement } & Group $^{3}$ & $\mathbf{M}$ & SD \\
\hline \multirow{3}{*}{1} & \multirow{3}{*}{$\begin{array}{l}\text { I cover the entire cost of my education (seminars, trainings, } \\
\text { lectures ...) myself. }\end{array}$} & 1 & 3,44 & 1,256 \\
\hline & & 2 & 4,06 & 1,126 \\
\hline & & 3 & 3,83 & 1,259 \\
\hline \multirow{3}{*}{2} & \multirow{3}{*}{$\begin{array}{l}\text { The employer is interested in my further training and } \\
\text { encourages me to transfer/present knowledge to my colleagues }\end{array}$} & 1 & 2,71 & 1,107 \\
\hline & & 2 & 2,61 & 1,169 \\
\hline & & 3 & 3,12 & 1,468 \\
\hline \multirow{3}{*}{3} & \multirow{3}{*}{$\begin{array}{l}\text { I regularly read professional literature and use the internet to } \\
\text { keep up with the latest developments in my line of work }\end{array}$} & 1 & 3,72 & 0,922 \\
\hline & & 2 & 3,61 & 0,999 \\
\hline & & 3 & 3,93 & 0,833 \\
\hline \multirow{3}{*}{4} & \multirow{3}{*}{$\begin{array}{l}\text { Command of foreign languages can help me in further training } \\
\text { or education }\end{array}$} & 1 & 4,09 & 0,810 \\
\hline & & 2 & 4,21 & 0,786 \\
\hline & & 3 & 4,29 & 0,822 \\
\hline \multirow{3}{*}{5} & \multirow{3}{*}{$\begin{array}{l}\text { I think it is necessary that educational institutions become more } \\
\text { involved in the process of lifelong learning }\end{array}$} & 1 & 4,00 & 0,720 \\
\hline & & 2 & 4,08 & 0,654 \\
\hline & & 3 & 4,25 & 0,726 \\
\hline
\end{tabular}

3 1. Founded by the regional government; 2 . Founded by the central government; 3 . Private institution 


\section{Discussion}

$60 \%$ of respondents agree with the statement that they cover the entire cost of their education on their own, whereas $22,3 \%$ disagree. Men agree with the above statement more frequently than women. It can be concluded that men have better access to education, but they also cover the costs on their own. With regard to the place of work, those respondents who work at institutions founded by the central government of at private institutions agree more frequently than those who work at an institution founded by the regional government. Employees at institutions founded by the central government work in a less favourable financial conditions, but it is surprising that the employees of private institutions cover the costs on their own more frequently than those working at the institutions founded by the regional government. An entrepreneur is willing to finance the professional training of the employees only if such training will pay off in the future. In comparison with the other three groups of respondents, respondents with 10 or more years of service more frequently agree with the above statement. Highly educated employees agree with the above statement more frequently. They have a greater chance for advancing their career - however, they also cover the costs themselves.

Furthermore, 29,3\% of respondents agree with the statement "The employer is interested in my further training and encourages me to convey/present knowledge to my colleagues", whereas $41,2 \%$ disagree. Younger employees tend to receive positive feedback from the institution and the employer, as opposed to their older colleagues. Respondents who work at a private institution agree with the statement more often than those who work at an institution founded by the regional or central government. An entrepreneur must have a good reason to allow an employee time and money for training, but at least the entrepreneur will demonstrate a degree of interest and expect appropriate feedback from the employee. On the other hand, an institution founded by the regional or central government may budget for some form of education of their employees, but in real life very few people are interested in information dissemination, further training or knowledge transfer within the institution or beyond.

$72,3 \%$ of respondents regularly read professional literature, and use the internet to keep up with the latest developments in their line of work in order to advance their professional education, whereas $12,5 \%$ do not agree with this statement. Respondents who work at a private institution agree with the statement more often, and at a statistically significant level, than those who work at an institution founded by the regional or central government. Employees of private institutions have greater motivation to stay in touch with their profession and expand their interest and knowledge in this way. There is a difference with respect to the length of service variable. Younger respondents with 10 years of service or less also gather new information and knowledge to a greater extent. Moreo- 
ver, staff with a higher level of education claim they read professional literature more and exhibit more interest for the latest developments in their line of work. $87 \%$ of respondents agree that a good command of foreign languages can help them in further training or education. Respondents aged 18 to 35 agree more frequently with this statement than those aged 36 to 65 . Younger respondents are more aware of the market changes and global developments in terms of future employment opportunities, for example in the EU countries. Naturally, older colleagues are already limited by their age, and therefore less competitive. Those with fewer years of service and those with a higher level of education also opt for additional training through foreign language courses, with the ultimate goal to develop professionally (by reading professional literature, attending lectures, seminars, conferences in a foreign language) and perhaps to further their education beyond Croatian borders.

$84,3 \%$ percent of respondents agree that it is necessary for educational institutions to become more involved in the process of lifelong learning. Respondents who work at a private institution agree with the statement more frequently than those who work at an institution founded by the regional or central government. Highly educated staff also agree with the said statement more often. The high percentage of positively oriented respondents is indicative of a pressing need for better networking between educational institutions, employers, and the healthcare system in the context of professional lifelong learning and education.

\section{Conclusion}

The survival of any society depends on the recognition of the concept of lifelong learning, both in terms of career development and the development of personal competences and resources which can help both individuals and society as a whole to thrive. We are referring to the development of an individual who will live by interacting with the environment, who learns throughout his or her life and career, and who in his or her pursuit should be provided with adequate conditions at all levels. Only through the close cooperation, synergy and transparent actions of all stakeholders in the process of lifelong learning and career development- above all educational institutions, followed by employers, future physical therapists, and the healthcare and social system as a whole - can a clear purpose and direction be formed to serve as a foundation for quality profession and the society of knowledge and excellence. Investing in human capital remains with the individuals who wish to prove to themselves, their peers, and their employers that change is possible.As we see it, the improvement is possible mainly within schooling system; firstly, students should be motivated towards lifelong learning in specific area of physical therapy and secondly, after they become employees should have the obligation to persist in managing a career. Further more, according to their abilities employers should make possible/give opportunity for employees both to work and study/attend various educational programmes. They should encourage working mobility and transparent 
approach towards information and scientific achievements within the profession. Lastly, the enormous gap is present between employers and employees, so we urgently need to work on our feedback potentials. Hopefully, this study will make a contribution and steer physiotherapy careers in a new direction.

\section{References}

[1] Zelenika, Ratko. Znanje - temelj društva blagostanja: obrazovna i znanstvena industrija. Rijeka : Ekonomski fakultet u Rijeci, 2007

[2] Pastuović, Nikola. Cjeloživotno učenje i promjene u školovanju. Zagreb : Odgojne znanosti, br. 10 (2008)

[3] Agency for Vocational Education and Training and Adult Education. White Paper on Croatian Education. 14. 5. 2009. http://www.asoo.hr. (Viewed 12. 11.2014)

[4] Croatian Association of People's Open Universities. Memorandum on Lifelong Learning: Bruxelles, 30.10.2000, SEC (2000) 1832: Commission staff working paper. http://www.hzpou.hr/?gid=5\&aid=26 (Viewed 20. 11.2014)

[5] Official Gazette of the Republic of Croatia. Act on Physiotherapy Profession, (NN 120/2008). 3. 10. 2008. http://narodne-novine.nn.hr/default.aspx (Viewed 5. 11.2014.)

[6] Beljo Lučić, Ružica et al. Hrvatski kvalifikacijski okvir - Uvod u kvalifikacije. Zagreb; Vlada Republike Hrvatske, Ministarstvo znanosti, obrazovanja i športa, 2009.

[7] Croatian Council of Physiotherapy. Rules on registers of the Croatian Council of Physiotherapy. 28. 12. 2012

[8] http://www.hkf.hr/propisiiobrascikomore/tabid/62/default.aspx (Viewed 5. 11. 2014). 